\title{
The Impact of Library Instruction on Undergraduate Student Success: A Four-Year Study
}

\section{Jennifer Rowe, Julie Leuzinger, Carol Hargis, and Karen R. Harker}

\begin{abstract}
During a four-year period, librarians collected student data by card-swiping undergraduate students who attended one of the core English composition class-based one-shot instruction sessions provided at a large state-supported doctoral-granting university. Data for students who attended library instruction was anonymized and compared to the same data points for students who were enrolled in the English class but did not attend library instruction. The authors compared student success indicators for the control and treatment groups (GPA, pass or fail status in course, and retention) and found a positive correlation between attending library instruction and student success.
\end{abstract}

\section{Introduction}

This paper reports on a four-year study undertaken by librarians at the University of North Texas, to compare variables of student success for students who participated in course-based one-shot library instruction sessions to the same indicators for students who did not receive library instruction. The authors, like so many others, were inspired by Oakleaf's 2010 report for ACRL on the value of academic libraries and felt compelled to elucidate the value of libraries and library instruction to both internal library administrators and university administration. ${ }^{1}$ The authors believed, based on their own anecdotal experiences, that library instruction does contribute positively to student success. With recommendations to employ correlations studies from scholars such as Oakleaf and Matthews in mind, the authors designed their own study. Since other researchers studying student success and library instruction reported mixed results, this study was designed to eliminate the limiting factors of those previous correlation studies. ${ }^{2}$

In 2012, librarians initiated a four-year period of collecting card-swipe data for students attending library instruction initiated by English composition class instructors. When data collection began, the authors had this basic research question in mind: is there a relationship

\footnotetext{
*Jennifer Rowe is Social Sciences and Community Engagement Librarian in Eagle Commons Library at the University of North Texas; email: jennifer.rowe@unt.edu. Julie Leuzinger is Library Learning Services Department Head and Women's and Gender Studies Subject Librarian at the University of North Texas Libraries; email: julie.leuzinger@ unt.edu. Carol Hargis is Humanities and Instruction Librarian at the University of North Texas Libraries Library Learning Services; email: carol.hargis@unt.edu. Karen R. Harker is Collection Assessment Librarian at the University of North Texas Libraries; email: karen.harker@unt.edu. (02021 Jennifer Rowe, Julie Leuzinger, Carol Hargis, and Karen R. Harker, Attribution-NonCommercial (https://creativecommons.org/licenses/by-nc/4.0/) CC BY-NC.
} 
between library instruction and student success? The variables used to measure student success were GPA, pass or fail status in the course, and retention (in other words, re-enrollment the semester following library instruction).

\section{Background}

The University of North Texas (UNT) is a Carnegie Tier One public research university with enrollment approaching 39,000 students and more than 5,000 faculty and staff. Twenty-four subject librarians support the research and instructional needs of the university's 38 doctoral degrees, 86 master's degrees, and 103 bachelor's degrees. Each subject librarian provides inperson one-shot instruction sessions, and many librarians are embedded into online courses, in support of distance students. The subject librarian assigned to the Department of English provides library instruction for the two English composition core classes, of which at UNT there are more than 70 sections offered per semester.

Given the research that already exists, several factors make the present study unique. The authors collected card-swipe data during a four-year period, providing a very large set of data. In addition, since card swiping was used, students included in the test group are only those students who actually attended library instruction rather than all students who registered for a class that received instruction, as was the case for the rest of the major studies on this same topic. The study focuses on students who received introductory library instruction during a core English composition class and only includes data for students enrolled in any section of one specific English composition class during the four-year study period. This single class eliminates the need to address potential variation in library instruction content and librarian instructors, as well as the need to normalize the data (course grade and GPA) to account for discipline-specific grading trends.

\section{Literature Review}

Although the project discussed herein is a form of library instruction assessment, some explanation is required on types of assessments. Based on the distinction that higher education scholars like Victor Borden have made between academic assessments that measure student learning outcomes vs. those that academies use for accountability and advocacy, library assessment can be separated into two categories: 1 ) those assessments that help improve instruction and programs and 2) those that help connect the library to measures of student success. ${ }^{3}$ Although there are some assessment methods that have the potential to both provide meaningful ways to improve programs and to demonstrate the library's relationship with student success, there is an inherent conflict between the two types of assessments. Information learned from program improvement assessment usually does not aggregate for public messaging, while information from accountability assessment does not provide meaningful program-level evaluation. This literature review will not cover program improvement assessment; instead, it will focus on only the literature covering library assessment using large-scale indicators of student success, such as GPA, retention, and graduation.

Due to increasing pressure to demonstrate value and to show the libraries' contribution to student success, many libraries have in recent years embarked on studies that demonstrate impact of academic library space use, material use, and library instruction on student retention, GPA, and graduation. Simply reporting counts of students through the doors, items circulated, or usage of services is no longer enough to show that the library positively influences 
student retention and graduation. University administrators increasingly want to see data that shows return on investment for library expenses and to know that the library is contributing to the success of students. With Oakleaf's ACRL Value of Academic Libraries report in mind, many librarians have been inspired to engage in research that has the potential to persuade administrators that library expenditures are well justified. ${ }^{4}$

The rest of this literature review will focus only on those studies that relied on large-scale student success indicators, such as GPA, retention, and graduation. There have been studies in the higher education literature linking use of campus facilities and spaces, ${ }^{5}$ including library spaces to student retention and graduation. ${ }^{6}$ Many recent studies from the library literature used library indicators from ARL, ACRL, and data about student retention and graduation from the Integrated Post-Secondary Education Data System via the National Center for Education Statistics. Some of those studies have found a relationship between higher spending on libraries and higher numbers of professional staff members in the library to better student success outcomes. ${ }^{7}$

Other studies have linked student use of library resources, including books, media items, and electronic resources to student success such as higher GPAs, better retention, and higher graduation rates. ${ }^{8}$ These types of studies date back to the 1960s when authors of two early studies analyzed student use of library materials and variables for retention and GPA, both showing correlations between the variables. ${ }^{9}$ More recently, librarians at University of Minnesota and at Indiana University have combined library use data from their libraries service points and electronic resources and compared with student data to draw positive correlations between library use and student success. ${ }^{10}$ Researchers at Hong Kong Baptist University were also able to make a positive correlation between student cumulative GPA and books and media checkouts. ${ }^{11}$ Librarians at Nevada State College performed a novel study that compared student use of electronic resources, captured by EZProxy logins, to GPA, retention, and academic standing and found a positive correlation between library use and student success. ${ }^{12}$

Studies that focus on the use of the library resources related to student success appear to provide evidence for a relationship between library use and student success. Studies that focus on library instruction and student success, however, have had mixed results and overall provide less direct evidence for correlation between library instruction and student success. The authors have chosen to omit from this discussion those studies that focused on for-credit library courses, and their effect on student success variables, as that format of library instruction is not an option at many large four-year universities.

In 2011, researchers at Hong Kong Baptist University completed another study with data for more than 8,000 students in which they used cumulative GPA and number of library workshops attended as their independent variables. They found that attendance at a greater number of library workshops had a positive correlation with GPA. ${ }^{13}$ Similarly, Bowles-Terry's 2012 study concluded that GPA was higher among graduating seniors who had library instruction in upper-level courses and that student success indicators reflect positive correlation with library instruction when students engage in library instruction sessions throughout their college years. ${ }^{14}$

In a 2012 study by librarians at Middle Tennessee State University, library instruction was the focus and was compared with student GPA and retention. The librarians analyzed data for first-time freshman who were enrolled in a class that received library one-shot instruction. They used data for a control group who did not attend library instruction for comparison. Their 
analysis showed no correlation between students attending library instruction and retention, but they did report a small correlation between students attending library instruction and higher GPA. These researchers recommend card swiping, to account for students who take classes that receive library instruction but do not attend class. ${ }^{15}$

Researchers at Stephen F. Austin University compared course grades for students who attended library instruction to grades for those who did not, and their results do not demonstrate a correlation between the library instruction and student success. ${ }^{16}$ Much like the Middle Tennessee librarians, researchers did not card-swipe; instead, they obtained lists of students enrolled in classes that received library instruction. This data collection method does not differentiate between the students who did not attend class the day of the library instruction and the students who did. Thus, their method may have resulted in some students being in the test group who do not belong there, and some students who did not attend class or library instruction are included in the test group rather than the control group.

Catalano and Phillips found that students who completed research assignments that required the use of library resources fared better regarding information literacy competency indicators and large-scale indicators, GPA, retention, and graduation. ${ }^{17}$ Researchers at Ohio State had mixed results measuring student GPA and persistence following a library assignment that was initiated by an academic advisor. They found a correlation between performing a library assignment and student success at smaller campuses; but, at the large central campus, there was no relationship between measured student success variables and completing the library assignment. ${ }^{18}$ In 2018, researchers at Saint Mary's College published their study that looked at GPA and library instruction for students across disciplines. Data for students who were enrolled in a class that received library instruction were obtained and transcripts were used to compare student GPAs for those students who were enrolled in a course that received library instruction vs. those students who were not. Their study was unique in that students who received library instruction were in a variety of different discipline classes. The authors normalized the data to account for different disciplinary grading procedures. They found an increase in GPA for students who participated in at least one library instruction session. ${ }^{19}$

Some authors in the library literature are critical of correlation studies that use large-scale indicators. Badke suggests moving away from attempts to correlate instruction with GPA and recommends using indicators that are more likely to allow for causal relationships between the measured variable and the instruction instead. ${ }^{20}$ Librarians at Virginia Commonwealth University, after finding no statistically significant relationship between library instruction and GPA, argue that GPA and re-enrollment are not sensitive enough variables for understanding the library's effect on student success. A student's GPA is a very large-scale indicator, and there are a great many factors that can influence this metric. ${ }^{21}$ Much has been written in the higher education literature covering the myriad different influences on student GPA, retention, and graduation. Structural characteristics of the university are thought to exert influence over student success: size of the institution, mission of the institution (whether teaching or research focused), class size and student to faculty ratio, and the level of faculty engagement. ${ }^{22}$ Institutional factors specific to the library, such as library staff size, library spending per student, and library collection size have also been shown to affect student success. ${ }^{23}$ Student behaviors such as alcohol use, effort and attention given to academics, engagement on campus, use of support services and recreational and other campus facilities, and time management strategies also can influence student success for the negative or the positive. ${ }^{24}$ Furthermore, student 
characteristics influence student success. Disability status, socioeconomic status, first language, precollege academic experience, self-esteem, emotional dysregulation and test anxiety, past violent victimization experiences, level of family support, first generation in college status, and the student being a parent can all play a role in the student's college success. ${ }^{25}$

Given the many and complex variables that affect student success, Gariepy, Peacemaker, and Colon claim that it is unreasonable to expect that the library instruction sessions attended will exert measurable control over a student's GPA. The authors acknowledge, however, that library research using GPA and retention as variables, if done well, has the potential to provide evidence to library or university administration of the library's value. ${ }^{26}$ The authors of one of the earliest library studies to attempt to measure effects of library instruction on student success variables - Selegean, Thomas, and Richman, in 1983-voice caution that library instruction efforts must be evaluated by variables that are more sensitive than the large-scale indicators. ${ }^{27}$ None of these large-scale student success correlation studies can claim causality of library instruction or library use to better student outcomes, and they certainly do not provide feedback/evidence for fine-tuning instructor performance; however, they have the potential to provide valuable talking points that libraries can use to advocate. Libraries can use the results of these correlation studies to demonstrate the potential of their important role in retaining and matriculating students. Whether students who use the library tend to do better in school or whether students who do better in school tend to use the library, the fact is that libraries play a role in educating students.

\section{Methodology}

\section{Research Question}

This research was guided by the question, "Is there a relationship between library instruction and student success?" The authors believed that the question was important to explore and that the research has the potential to add to the growing body of literature that correlates library use with student success measures.

\section{Data Collection}

Before data collection began in 2012, the authors received approval from the Institutional Review Board. Since the data were to be anonymized even before it reached the authors, the authors were not required to obtain informed consent from each student whose data was used in the study.

Study participants were undergraduate students who attended a library instruction session with their English 1320 composition course between 2012 and 2016. Participation in a library instruction session is entirely voluntary for the English composition section instructors. Some instructors bring their classes to the library for one-shot bibliographic instruction and some do not. Students were asked to swipe their university ID cards through a card reader during the library instruction session, at which time the information was recorded and stored. The swipe data were organized in the institution's student information system by semester and year, flagging the students' instruction participation to a point in time. More than 3,000 students who attended English Composition library instruction sessions swiped their IDs during the four-year study period. At the end of the study period, the authors requested the data from the Data Analytics and Institutional Research (DAIR) office, which controls access to the institution's student information. In addition to the 
3,000 students who attended library instruction, the authors were also able to obtain data for the more than 6,000 students who were enrolled in sections of the English 1320 course but who did not attend library instruction, because either they were not present in class or because they were enrolled in a section that did not participate in library instruction. In total, more than 10,000 students were included in the final data set. ${ }^{28}$ As mentioned above, having the data for students who did not attend library instruction allowed the authors to have a control group with which to compare the original data for students who did attend library instruction (treatment group).

Before the authors received the data, the DAIR office anonymized the student data by assigning fake ID numbers to each student, and then added the following information for each of the 10,000 students:

- grades in the English composition class

- semester GPA (for the semester they participated in the library instruction session) and final GPA

- graduation status (if applicable)

- re-enrolled status the semester following their library instruction session (retention)

The authors also received demographic data, such as first-generation college status, student major, gender and ethnicity, and transfer or new student status.

\section{Statistical Analyses}

The authors used Statistical Package for the Social Sciences (IBM SPSS) for their analyses. Basic descriptive statistics were used, comparing those who received library instruction (treatment) with those who did not (control) on baseline and outcome measures. The key measures tested were pass/not passed the English 1320 course, change in GPA, increased or not-increased GPA, and continuation or graduation at UNT. To test for statistical significance, the authors used the two-sample $t$-test for the continuous variable, change in GPA outcome, with a threshold of $p$ $\leq 0.01$, a strong threshold due to the large size of the groups. The authors also compared the distributions of those who did or did not pass the course, those who did or did not increase their GPA, and those who did or did not continue or graduate. Risk estimates were calculated (odds ratios of risk ratios) and tested using Pearson Chi-square tests. The odds ratio of each successful outcome among the treatment group was calculated by dividing the risk of each successful outcome in the treatment group relative to the control group by the relative risk of the nonsuccessful outcome. The authors report here the odds ratio point estimate, the 95 percent confidence interval, and the $p$-value of the Chi-square test, with a probability threshold of significance of $p<0.01$.

\section{Results}

\section{Basic Descriptive Statistics}

There were 10,147 student records in the data set, of which 3,530 (34.8\%) were in the Library Instruction (treatment) group. In addition to the size of the groups, there were other baseline differences, notably binary gender status $(43.5 \%$ men in the Library Instruction group vs. $46 \%$ in control group), minority status ( $51 \%$ vs. $48 \%$ White), admission status (7\% vs. $4.7 \%$ first-time-in-college) and academic measures (1,077 vs. 1,065 mean SAT; 2.31 vs. 2.24 mean GPA). There were a few similarities between the groups, most notably the distribution of first-generation students (about 38\% each) (see table 1). 


\begin{tabular}{|c|c|c|c|c|c|}
\hline \multicolumn{6}{|c|}{$\begin{array}{c}\text { TABLE } 1 \\
\text { Basic Descriptive Statistics }\end{array}$} \\
\hline & \multicolumn{2}{|c|}{ Library Instruction } & \multicolumn{2}{|c|}{ Control } & \multirow[t]{2}{*}{$\mathbf{p}$} \\
\hline & $\mathbf{N}$ & $\%$ & $\mathbf{N}$ & $\%$ & \\
\hline Binary Gender & & & & & 0.009 \\
\hline Men & 1,537 & $43.54 \%$ & 3,072 & $46.43 \%$ & \\
\hline Women & 1,993 & $56.46 \%$ & 3,542 & $53.53 \%$ & \\
\hline Total & 3,530 & $100.00 \%$ & 6,617 & $100.00 \%$ & \\
\hline Ethnic Group & & & & & 0.081 \\
\hline African-American & 570 & $16.15 \%$ & 1,197 & $18.09 \%$ & \\
\hline American Indian & 51 & $1.44 \%$ & 102 & $1.54 \%$ & \\
\hline Asian/Pacific Islander & 180 & $5.10 \%$ & 368 & $5.56 \%$ & \\
\hline Hispanic & 830 & $23.51 \%$ & 1,572 & $23.76 \%$ & \\
\hline Nonresident & 65 & $1.84 \%$ & 134 & $2.03 \%$ & \\
\hline Other & 27 & $0.76 \%$ & 56 & $0.85 \%$ & \\
\hline White & 1,807 & $51.19 \%$ & 3,185 & $48.13 \%$ & \\
\hline Total & 3,530 & $100.00 \%$ & 6,617 & $100.00 \%$ & \\
\hline Minority Status & & & & & 0.003 \\
\hline \begin{tabular}{l|l} 
& White \\
\end{tabular} & 1,807 & $51.19 \%$ & 3,185 & $48.13 \%$ & \\
\hline Nonwhite & 1,723 & $48.81 \%$ & 3,432 & $51.87 \%$ & \\
\hline Total & 3,530 & $100.00 \%$ & 6,617 & $100.00 \%$ & \\
\hline Admission Status & & & & & $<0.001$ \\
\hline First Time in College & 256 & $7.25 \%$ & 309 & $4.67 \%$ & \\
\hline Continuing Student & 2,851 & $80.76 \%$ & 5,468 & $82.64 \%$ & \\
\hline New Undergraduate & 421 & $11.93 \%$ & 830 & $12.54 \%$ & \\
\hline New Graduate & 2 & $0.06 \%$ & 7 & $0.11 \%$ & \\
\hline Total & 3,530 & $100.00 \%$ & 6,617 & $100.00 \%$ & \\
\hline Declared Major Group & & & & & 0.003 \\
\hline Arts & 716 & $20.28 \%$ & 1,328 & $20.07 \%$ & \\
\hline Business & 740 & $20.96 \%$ & 1,608 & $24.30 \%$ & \\
\hline Humanities & 415 & $11.76 \%$ & 734 & $11.09 \%$ & \\
\hline Interdisciplinary & 356 & $10.08 \%$ & 724 & $10.94 \%$ & \\
\hline Social Sciences & 424 & $12.01 \%$ & 703 & $10.62 \%$ & \\
\hline Social Services \& Health Care & 522 & $14.79 \%$ & 908 & $13.72 \%$ & \\
\hline STEM & 178 & $5.04 \%$ & 299 & $4.52 \%$ & \\
\hline Unknown & 179 & $5.07 \%$ & 313 & $4.73 \%$ & \\
\hline Total & 3,530 & $100.00 \%$ & 6,617 & $100.00 \%$ & \\
\hline First-Generation Status & & & & & 0.334 \\
\hline \begin{tabular}{l|l} 
& Yes \\
\end{tabular} & 1,332 & $37.73 \%$ & 2,575 & $38.91 \%$ & \\
\hline No & 1,730 & $49.01 \%$ & 3,221 & $48.68 \%$ & \\
\hline Unknown & 468 & $13.26 \%$ & 821 & $12.41 \%$ & \\
\hline Total & 3,530 & $100.00 \%$ & 6,617 & $100.00 \%$ & \\
\hline \multicolumn{6}{|l|}{ Baseline Scores } \\
\hline Mean ACT & 993 & 23.06 & 1,811 & 23.17 & 0.044 \\
\hline Mean SAT & 2,121 & $1,076.69$ & 3,942 & $1,064.99$ & 0.001 \\
\hline Mean GPA & 3,530 & 2.31 & 6,614 & 2.24 & 0.011 \\
\hline
\end{tabular}




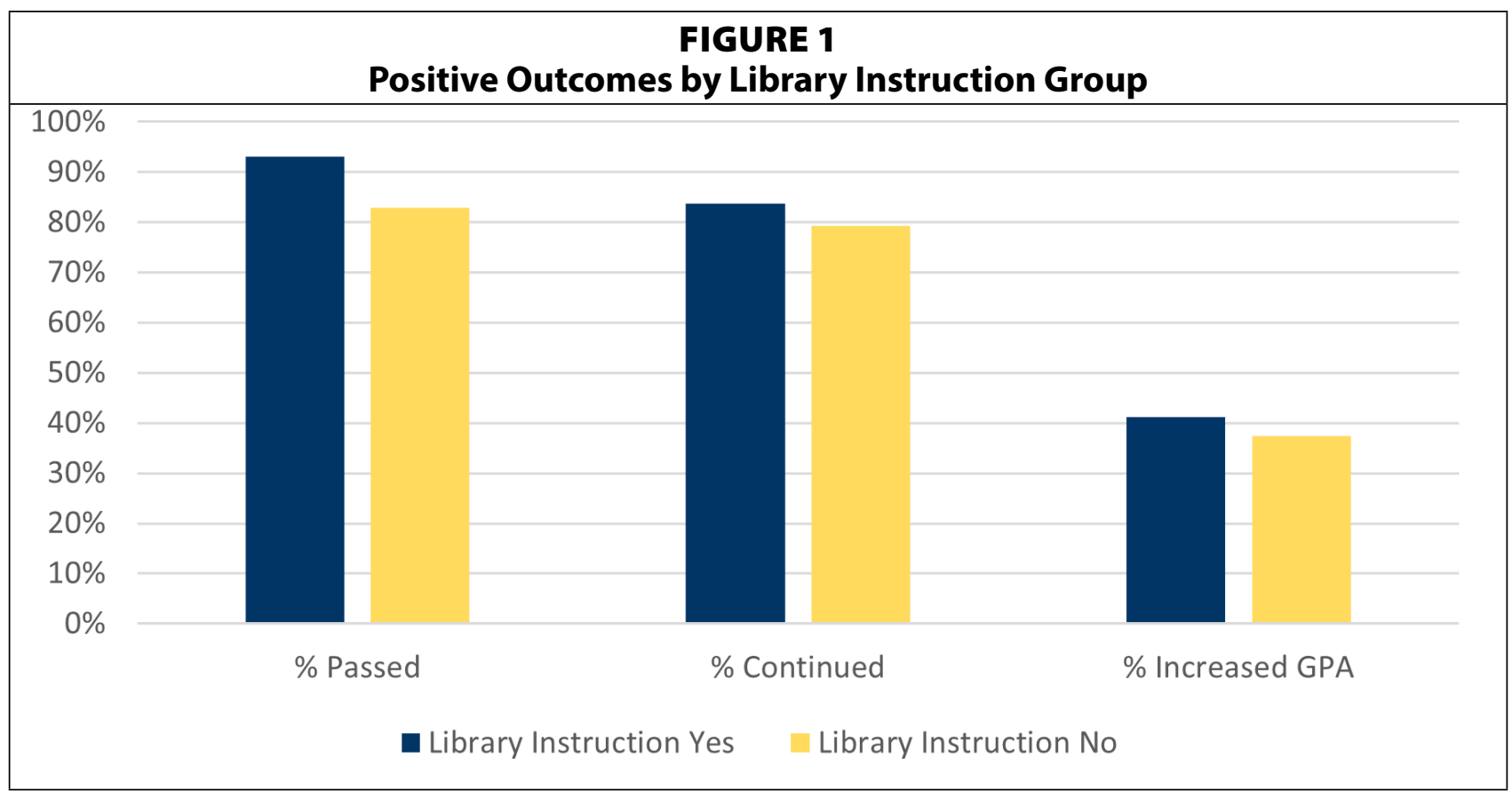

\section{Passed English 1320}

The first outcome discussed is key to most other outcomes - passing the English 1320 course. The authors conducted a cross-tabulation analysis of those who did or did not pass by group (those who did or did not receive library instruction). The categories of pass/not passed were determined by final grade received. Those in the Pass group received an A, B, C or D; all others were included in the Not Pass group. It was important to include all students, even those given an "Incomplete" or "Withdrawn" or other grade, because completion of course is a key factor in retention. Of all students in the data set, $86.5 \%$ passed. Of those who received library instruction, 93\% passed; of those who did not receive library instruction, fewer than

\begin{tabular}{|c|c|c|c|}
\hline \multicolumn{4}{|l|}{$\begin{array}{c}\text { TABLE } 2 \\
\text { Risk Estimates }\end{array}$} \\
\hline & \multirow[t]{2}{*}{ Value } & \multicolumn{2}{|c|}{ 95\% Confidence Interva } \\
\hline & & Lower & Upper \\
\hline Odds Ratio $\left(\mathrm{RR}_{1} / \mathrm{RR}_{2}\right)$ & 2.783 & 2.407 & 3.218 \\
\hline $\mathrm{RR}_{1}$ of passing within Library instruction cohort & 1.123 & 1.107 & 1.139 \\
\hline $\mathrm{RR}_{2}$ of not passing within Library instruction group & 0.403 & 0.353 & 0.461 \\
\hline $\mathrm{N}$ & 10,147 & & \\
\hline Odds Ratio $\left(\mathrm{RR}_{1} / \mathrm{RR}_{2}\right)$ & 1.167 & 1.064 & 1.281 \\
\hline $\mathrm{RR}_{1}$ of increased GPA for Library instruction cohort & 1.098 & 1.039 & 1.161 \\
\hline $\mathrm{RR}_{2}$ of GPA not increased for Library instruction cohort & 0.941 & 0.907 & 0.977 \\
\hline $\mathrm{N}$ & 8,260 & & \\
\hline Odds Ratio $\left(\mathrm{RR}_{1} / \mathrm{RR}_{2}\right)$ & 1.343 & 1.207 & 1.496 \\
\hline $\mathrm{RR}_{1}$ of continuing among the Library instruction cohort & 1.056 & 1.036 & 1.076 \\
\hline $\mathrm{RR}_{2}$ of not continuing among the Library instruction cohort & 0.786 & 0.719 & 0.859 \\
\hline $\mathrm{N}$ & 10,147 & & \\
\hline
\end{tabular}


$84 \%$ passed (see Figure 1). Thus, the risk of passing for those who received instruction relative to those who did not receive instruction was 1.123 (95\% CI: 1.11-1.14), while the RR of not passing for the same group relative to control was 0.40 (95\% CI: 0.35-0.46).

The odds ratio (OR) expressing the impact of library instruction on passing the English 1320 course was 2.78 (95\% CI: 2.41-3.22) (calculated by [RR of passing among Library group] / [RR of not passing among Library group]) (see table 2). Thus, those who received library instruction were nearly three times more likely to pass than those who did not. This difference between the two proportions was tested using Chi-square, and the result was statistically significant at $p<0.001$.

\section{Increasing GPA}

The analysis of change in GPA requires two measures: a beginning GPA and a cumulative GPA that includes the semester of the English 1320 course. This calculation was limited to those students who had a GPA before entering the semester during which they took the English 1320 class. Transfer students and first-semester-in-college students, who do not have a beginning GPA, were excluded from this analysis (17.5\% of all students in the sample set).

Of the remaining 82.5 percent of students in the sample data set, the beginning cumulative GPA for those who received library instruction was 2.83, compared with 2.68 for those who did not receive the instruction. This difference of 0.15 points was statistically significant. The semester GPA of those who received instruction was 2.82 compared to 2.55 for those who did not receive instruction (0.27 points lower); this difference was also statistically significant. Similarly, the end cumulative GPA for those who received instruction was 2.86, compared with 2.67 for those who did not. This 0.19 point difference was also statistically significant. The change in cumulative GPA for those who received the library instruction was +0.028 , compared with a decrease of 0.006 points among those who did not receive the instruction, a difference of 0.034 points.

The authors also conducted a cross-tabulation analysis to estimate the probability of positive change in GPA for students who received library instruction and students who did not receive library instruction. Of the 82.5 percent of students for which this analysis applies, 38.7 percent increased their GPA. Of those who did not receive library instruction, 37.5 percent increased their GPA. Of those who did receive library instruction, 41.1 percent increased their GPA, for a difference of 3.7 percentage points between the two groups (see table 2).

The cross-tabulation analysis of the two variables, which included a Pearson Chi-square analysis, yielded an odds ratio point estimate of 1.167 (95\% CI: 1.064-1.281, $p<0.01$ ) (see table 2 ). If the library instruction made a positive impact, then the risk of negative change should be greater than 1 . Thus, undergraduate students who are not first time in college and who attended a library instruction session at the UNT Libraries were 16.7 percent more likely to see an increase in their GPA.

\section{Retention}

For this study, the authors defined retention as continued enrollment (or graduation) in the following long semester. The same kind of analysis as described above was performed, comparing the odds of continuing the next semester for those who did and did not receive library instruction. For this calculation, the authors included all students, of whom 35 percent received library instruction and 81 percent continued or re-enrolled the following semester. Of 
those who did not receive library instruction, 79.3 percent continued, while of those who did receive library instruction, 83.7 percent continued, a difference of 4.4 percentage points more for those who received library instruction (see figure 1). The authors tested the differences between relative risk estimates of the groups using Pearson Chi-square. The point estimate of the odds ratio (OR) was 1.343 (95\% CI: 1.207-1.496, $p \leq 0.001$ ) (see table 2). Thus, undergraduate students who attended a library instruction session at the UNT Libraries were 34.3 percent more likely to continue the following semester than those who did not.

\section{Discussion}

While participating in library instruction is not solely responsible for student success in the form of higher student retention rates or increase in GPA, when considered together, as discussed in the literature review, it is very compelling evidence to suggest a relationship between library instruction and student success. This increase, coupled with the more likely pass rate for students who participated in library instruction, provides evidence that attending library instruction correlates to student success. This study has several advantages over other similar studies of outcomes based on library services. The most important of these is the large number of participants (more than 10,000 students) and the relatively long period of time covered (four years). Additionally, since the authors used card swiping to collect data, the control and study groups were truly distinct. Furthermore, there were several class sections (72), ensuring increased chance of randomization.

This article is by no means a blanket endorsement for one-shot library instruction. The authors acknowledge the limitations of that method of teaching and believe collaboratively creating meaningful research assignments with faculty has the potential to be far more impactful for long-term student success in achieving the threshold concepts discussed in the ACRL Framework for Information Literacy for Higher Education..$^{29}$ This article does affirm the valuable role subject librarians appear to play in student success in support of teaching and learning.

\section{Limitations}

A few limitations warrant discussion here. First, the students were not randomly assigned to sections that did or did not receive library instruction. The section instructors decided whether to require library instruction, and students could select sections based on instructors. This could explain the relatively higher beginning GPA of students who received library instruction. Higher-achieving students may be aware of the higher-quality instructors who tended to require such instruction and purposefully choose these sections. Regardless of the reasons, the sample data set clearly shows that the students who received library instruction had a higher GPA at the start of the semester than those who did not receive the library instruction. This could affect the outcomes, even when normalized for analysis.

\section{Further Research}

The authors did find some interesting results regarding first-generation college students that led them to believe that this population warrants further study. The positive impacts of receiving library instruction appear lower for first-generation students in general, and the authors believe this could be a ripe area for additional research.

In addition, a long-term study on the impact of collaboratively created research assignments between faculty and subject librarians as mentioned above could be a beneficial future 
step for this area of research, though this type of study may have many similar limitations as previous research studies have had regarding student success and one-shot instruction.

\section{Conclusion}

The original research question - "Is there a relationship between library instruction and student success?" - was answered through this study in the affirmative; however, library instruction is one factor among many that positively correlates to student success. Through this research, the authors were exposed to the amazing things that other academic and support units on campus are doing to impact student success and acknowledge there is great potential for more collaboration with those groups.

The authors hope that the positive results in this study can be generalizable enough to other similar institutions to allow for advocacy in showing the value of library instruction in supporting student success, as well as contributing to the body of research therein.

\section{Acknowledgment}

The authors would like to acknowledge the contributions of Ms. Gayla Byerly, retired Instruction and Assessment Librarian. Gayla is the visionary librarian who was inspired to conduct this research and began the initial data collection. When she retired in 2016, she entrusted the data set to the authors for analysis.

\section{Notes}

1. Association of College and Research Libraries (ACRL), “Value of Academic Libraries: A Comprehensive Research Review and Report" (2010), www.ala.org/acrl/sites/ala.org.acrl/files/content/issues/value/val_report. pdf.

2. Megan Oakleaf, "Correlating Library Services, Expertise, and Resources with Student Learning," Information Outlook 18, no. 2 (2014): 13-16; Joseph R. Matthews, "Assessing Library Contributions to University Outcomes: The Need for Individual Student Level Data," Library Management 33, no. 6/7 (2012): 389-402.

3. Victor M.H. Borden, "The Accountability/Improvement Paradox," Inside Higher Ed 20 (2010), www.insidehighered.com/node/19231/atom.xml.

4. ACRL, "Value of Academic Libraries."

5. Brent Mallinckrodt and William E. Sedlacek, "Student Retention and the Use of Campus Facilities by Race," NASPA Journal 46, no. 4 (2009): 566-72; Ronald Huesman Jr. et al., “Gym Bags and Mortarboards: Is Use of Campus Recreation Facilities Related to Student Success?" NASPA Journal 46, no. 1 (2009): 50-71.

6. Deborah Goodall and David Pattern, "Academic Library Non/Low Use and Undergraduate Student Achievement," Library Management 32, no. 3 (2011): 159-70.

7. Gregory A. Crawford, “The Academic Library and Student Retention and Graduation: An Exploratory Study," portal: Libraries and the Academy 15, no. 1 (2015): 41-57; Gregory A. Crawford, "Pennsylvania Academic Libraries and Student Retention and Graduation: A Preliminary Investigation with Confusing Results," Pennsylvania Libraries 2, no. 2 (2014): 129-41; Mark Emmons and Frances C. Wilkinson, "The Academic Library Impact on Student Persistence," College E Research Libraries 72, no. 2 (2011): 128-49; Elizabeth M. Mezick, "Relationship of Library Assessment to Student Retention," Journal of Academic Librarianship 41, no. 1 (2015): 31-36; Boris Teske, Michael DiCarlo, and Dexter Cahoy, "Libraries and Student Persistence at Southern Colleges and Universities," Reference Services Review 41, no. 2 (2013): 266-79.

8. DeeAnn Allison, "Measuring the Academic Impact of Libraries," portal: Libraries and the Academy 15, no. 1 (2015): 30-40.

9. Lloyd A. Kramer and Martha B. Kramer, "The College Library and the Drop-Out," College E Research Libraries 29, no. 4 (1968): 310-12; Patrick Barkey, "Patterns of Student Use of a College Library," College \& Research Libraries 26, no. 2 (1965): 115-18.

10. Krista M. Soria, Jan Fransen, and Shane Nackerud, “Library Use and Undergraduate Student Outcomes: New Evidence for Students' Retention and Academic Success," portal: Libraries and the Academy 13, no. 2 (2013): 147-64; Krista M. Soria, Jan Fransen, and Shane Nackerud, "Beyond Books: The Extended Academic Benefits 
of Library use for First-Year College Students," College \& Research Libraries 78, no. 1 (2017): 8-22; Angie Thorpe et al., "The Impact of the Academic Library on Student Success: Connecting the Dots," portal: Libraries and the Academy 16, no. 2 (2016): 373-92.

11. Shun Han Rebekah Wong and T.D. Webb, “Uncovering Meaningful Correlation between Student Academic Performance and Library Material Usage," College \& Research Libraries 72, no. 4 (2011): 361-70.

12. Tiffany LeMaistre, Qingmin Shi, and Sandip Thanki, “Connecting Library Use to Student Success," portal: Libraries and the Academy 18, no. 1 (2018): 117-40.

13. Shun Han Rebekah Wong and Dianne Cmor, "Measuring Association between Library Instruction and Graduation GPA," College E Research Libraries 72, no. 5 (2011): 464-73.

14. Melissa Bowles-Terry, "Library Instruction and Academic Success: A Mixed-Methods Assessment of a Library Instruction Program," Evidence Based Library and Information Practice 7, no. 1 (2012): 82-95.

15. Jason M. Vance, Rachel Kirk, and Justin G. Gardner, "Measuring the Impact of Library Instruction on Freshman Success and Persistence," Communications in Information Literacy 6, no. 1 (2012): 49-58.

16. Priscilla Coulter, Susan Clarke, and Carol Scamman, "Course Grade as a Measure of the Effectiveness of One-Shot Information Literacy Instruction," Public Services Quarterly 3, no. 1/2 (2007): 147-63.

17. Amy Jo Catalano and Sharon Rose Phillips, "Information Literacy and Retention: A Case Study of the Value of the Library," Evidence Based Library and Information Practice 11, no. 4 (2016): 2-13.

18. Elizabeth L. Black and Sarah Anne Murphy, "The Out Loud Assignment: Articulating Library Contributions to First-Year Student Success," Journal of Academic Librarianship 43, no. 5 (2017): 409-16.

19. Ula Gaha, Suzanne Hinnefeld, and Catherine Pellegrin, "The Academic Library's Contribution to Student Success: Library Instruction and GPA," College \& Research Libraries 79, no. 6 (2018): 737-46.

20William Badke, "Infolit and GPA," Online Searcher 38, no. 1 (2014): 68-70.

21. Laura W. Gariepy, Bettina Peacemaker, and Valeriana Colo, "Stop Chasing Unicorns," Performance Measurements $\mathcal{E}$ Metrics 18, no. 2 (2017): 103-09.

22. Linda K. Lau, "Institutional Factors Affecting Student Retention," Education-Indianapolis then Chula Vista 124, no. 1 (2003): 126-36.

23. Mezick, "Relationship of Library Assessment to Student Retention," 31-36; Emmons and Wilkinson, "The Academic Library Impact on Student Persistence," 128-49.

24. James M. Conway and Joanne DiPlacido, "The Indirect Effect of Alcohol Use on GPA in First-Semester College Students: The Mediating Role of Academic Effort," Journal of College Student Retention: Research, Theory $\mathcal{E}$ Practice 17, no. 3 (2015): 303-18; George D. Kuh et al., "Unmasking the Effects of Student Engagement on First-Year College Grades and Persistence," Journal of Higher Education 79, no. 5 (2008): 540-63; Lau, "Institutional Factors Affecting Student Retention," 126-36; Huesman et al., "Gym Bags and Mortarboards," 50-71; Mallinckrodt and Sedlacek, "Student Retention and the Use of Campus Facilities by Race," 566-72; Jordan Thibodeaux et al., "FirstYear College Students' Time Use: Relations with Self-Regulation and GPA," Journal of Advanced Academics 28, no. 1 (2017): 5-27;

25. James T. Herbert et al., "Persistence and Graduation of College Students Seeking Disability Support Services," Journal of Rehabilitation 80, no. 1 (2014): 22-32; Daniel A. Sass et al., "A Structural Model for Predicting Student Retention," Review of Higher Education 42, no. 1 (2018): 103-35; Rebecca Zwick and Jeffrey G. Sklar, "Predicting College Grades and Degree Completion Using High School Grades and SAT Scores: The Role of Student Ethnicity and First Language," American Educational Research Journal 42, no. 3 (2005): 439-64; Jeffery E. Aspelmeier et al., "Self-Esteem, Locus of Control, College Adjustment, and GPA among First- and ContinuingGeneration Students: A Moderator Model of Generational Status," Research in Higher Education 53, no. 7 (2012): 755-81; Samantha D. Hartman, David T. Wasieleski, and Mark A. Whatley, "Just Breathe: The Effects of Emotional Dysregulation and Test Anxiety on GPA," College Student Journal 51, no. 1 (2017): 142-50; Majel R. Baker et al., "Sexual Victimization History Predicts Academic Performance in College Women," Journal of Counseling Psychology 63, no. 6 (2016): 685-92; Wen Cheng, William Ickes, and Lesley Verhofstadt, "How Is Family Support Related to Students' GPA Scores? A Longitudinal Study," Higher Education 64, no. 3 (2012): 399-420; Ian Godfrey et al., "Supporting Student Retention and Success: Including Family Areas in an Academic Library," portal: Libraries and the Academy 17, no. 2 (2017): 375-88.

26. Gariepy, Peacemaker, and Colon, “Stop Chasing Unicorns,” 103-09.

27. John Cornell Selegean, Martha Lou Thomas, and Marie Louise Richman, "Long-Range Effectiveness of Library Use Instruction," College \& Research Libraries 44, no. 6 (1983): 476-80.

28. The data is freely available at: digital.library.unt.edu/ark:/67531/metadc987449/.

29. Association of College and Research Libraries, Framework for Information Literacy for Higher Education (2016), www.ala.org/acrl/standards/ilframework. 